\title{
NEWS-målinger trygger sykepleiere i den tverrprofesjonelle kommunikasjonen
}

NEWS kan styrke sykepleieres kliniske vurderingsevne. Men ikke alle er positivt innstilt til verktøyet, og vår erfaring er at både kunnskapen om og opplæringen i NEWS er begrenset.

Jenny Kjøl

Sykepleierstudent

Avdeling for helse- og sosialfag, Høgskolen i Molde

Lise Melbye

Sykepleierstudent

Avdeling for helse- og sosialfag, Høgskolen i Molde

Ingunn Pernille Mundal

Førsteamanuensis

Avdeling for helse- og sosialfag, Høgskolen i Molde

Sykepleie

Litteraturstudie

Respirasjon

Symptom

Risiko

Sykepleien 2020108 (83082) (e-83082)

DOI: 10.4220/Sykepleiens.2020.83082

\section{Hovedbudskap}


Sykepleiere praktiserer NEWS ulikt og har ulike erfaringer med nytten av dette verktøyet. Årsaken kan være varierende kliniske vurderinger og intuisjon samt manglende tverrprofesjonell kompetanse og kommunikasjon. Selv om utdanningsprogrammene har bidratt til å forbedre kompetansen og kunnskapen om bruken av NEWS, tyder mye på at opplæringen i skåringsverktøyet fortsatt er begrenset.

Skåringsverktøyet National Early Warning Score (NEWS) skal hjelpe sykepleiere til å kunne se endringer i pasientens vitale tegn over tid samt å oppdage forverring hos pasienten.

Erfaringer fra praksis viser at sykepleiere bruker verktøyet ulikt. Dette kan ha alvorlige konsekvenser for pasientenes videre oppfølging og behandling, og det er derfor viktig å unders $\varnothing$ ke bruken av NEWS nærmere.

\section{Bakgrunn}

NEWS ble innført i Norge som et ledd i

pasientsikkerhetsarbeidet og skal hjelpe sykepleiere og annet helsepersonell til lettere å kunne vurdere risiko for alvorlig forverring i helsetilstanden hos pasienter, som for eksempel sepsis, hjertestans og uventet $\mathrm{d} \varnothing \mathrm{d}(1)$.

NEWS kan være med på å forutsi død innen 24 timer (1), bidra til tidlig gjenkjennelse av pasienter med mulig eller kritisk sykdom og gi bedre vitale målinger (2). I tillegg kan verktøyet redusere kostnader og liggetid (3).

\section{三 «NEWS bidrar til konsis kommunikasjon mellom partene i helsevesenet.»}

NEWS er en forbedret utgave av MEWS ( $\mathrm{M}=$ modified), som ble utviklet for å standardisere kartleggingen (4). I 2017 ble NEWS oppgradert til NEWS2 (5) og anbefalt brukt både i sykehus og i kommunale helse- og omsorgstjenester (1).

\section{NEWS2 identifiserer forverring hos covid-19- pasienter}


NEWS er et godt verktøy for å følge pasientutvikling over tid og bidrar til konsis kommunikasjon mellom partene i helsevesenet. Ikke minst har NEWS2 vist seg å være et nyttig hjelpemiddel for å identifisere forverring hos covid-19pasienter (6). Nyere forskning viser at sykepleieres kompetanse i bruken av skåringsverktøy er med på å forbedre overvåkningen av pasienter, men at effekten av slike skåringsverktøy er usikker (2).

Fagartikkelen er skrevet med utgangspunkt i en bacheloroppgave i sykepleie der vi med bakgrunn i vår erfaring med ulik bruk av NEWS blant sykepleiere $\varnothing$ nsket å se nærmere på hva forskningen sier om sykepleieres erfaringer med bruk av NEWS.

\section{Metode}

Studien er en systematisk litteraturstudie, der vi inkluderte elleve kvalitative forskningsartikler med sykepleieperspektiv publisert mellom 2010 og 2020 . Vi gjennomførte $s \varnothing \mathrm{k}$ i MEDLINE, Ovid Nursing og Wiley Online Library med søkeordene nurse, National Early Warning, Early Warning, Modified Early Warning, EWS, MEWS, experience og use.

Et PICO-skjema (se faktaboks under) ble brukt for å systematisere og strukturere databases økene (7). Søkene ble gjort med alle ord, inkludert søkeord fra PICO-skjemaet og trunkeringer, og ga til sammen 178 treff.

Etter gjennomlesning av 41 abstrakter ble 30 artikler ekskludert. De 11 artiklene som ble inkludert i studien, fylte inklusjonskriteriene om at artiklene skulle være kvalitative og etisk vurderte engelsk- eller skandinaviskspråklig originalartikler, at de skulle være basert på studier gjennomført i vestlige land, og at de skulle omhandle skåringsverktøy for voksne.

Oppsummert forskning og artikler som handlet om skåringsverktøy for barn og gravide, samt artikler med kvantitative metoder, ble ekskludert. Artiklene ble analysert ved hjelp av Evans analysemodell (8).

\section{PICO}


I kunnskapsbasert praksis er det viktig å gjøre spørsmålet (problemstillingen) tydelig og presist. PICO er et verktøy som hjelper deg med dette. Når du har formulert et presist spørsmål, bør du bestemme hvilket kjernespørsmål du står overfor. Dette vil hjelpe deg når du skal søke etter forskning om spørsmålet ditt.

PICO gir struktur og klargjør spørsmålet for litteraturs $\varnothing \mathrm{k}$, utvelgelse og kritisk vurdering av litteraturen. PICO er en forkortelse for elementer som ofte vil være med i et spørsmål:

- P: Population/patient/problem. Hvilken pasientgruppe eller populasjon dreier det seg om?

- I: Intervention. Hva er det med denne pasientgruppen du er interessert i? Er det tiltak som er iverksatt (intervensjon, eksponering)?

- C: Comparison. Ønsker du å sammenlikne to typer tiltak? I så fall skal det andre tiltaket stå her (for eksempel dagens praksis).

- O: Outcome. Hvilke endepunkter er du interessert i?

Kilde: Kunnskapssenteret

\section{Hvilke erfaringer har sykepleiere med NEWS?}

Særlig tre hovedfunn pekte seg ut som gjennomgående og viktige i artiklene. Disse funnene handlet om nytteverdi, kliniske vurderinger og intuisjon, og tverrprofesjonell kompetanse og kommunikasjon (se figur 1).

\section{Nytteverdien oppleves forskjellig av erfarne og nyutdannede}

Samtlige studier viste at sykepleiere hadde ulike erfaringer med generell bruk av NEWS, og at de opplevde NEWS som nyttig for å oppdage endringer i vitale målinger og forverring i pasientens tilstand (9-19).

Mens noen sykepleiere erfarte at NEWS-skåring var en arbeidsoppgave de måtte utføre $(14,15)$, hadde arbeidsmengde og kultur på avdelingen mye å si for hvordan NEWS ble brukt og prioritert (15). Noen sykepleiere opplevde også at NEWS styrket følelsen av ansvarlighet, selvsikkerhet og autoritet (9, 11). 
Henholdsvis erfarne og nyutdannede sykepleiere hadde ulike erfaringer når det gjaldt nødvendigheten av å bruke NEWS $(11,15,16)$. Mens nyutdannede sykepleiere opplevde at NEWS minnet dem på å unders $\varnothing$ ke pasienter $(15,16)$, anså erfarne sykepleiere NEWS som et verktøy til å identifisere potensielle endringer (11).

Flere studier viste at NEWS hjalp sykepleiere til å bli mer bevisst på for eksempel respirasjonsfrekvens $(15,16)$. En sykepleier sa det slik:

«Vel, jeg hadde en pasient som kom inn, som faktisk så ut til å være i ganske god form bortsett fra forhøyet respirasjonsfrekvens. Før vi hadde lært noe om NEWS, tenkte jeg ikke mye på respirasjonsfrekvensen ... Så forsto jeg at respirasjonsfrekvensen ofte er de første tingene som påvirkes når pasienten forverres.» (15)

\section{Objektive målinger styrker sykepleiernes kliniske vurderinger}

Flere studier viste at NEWS bidro til å styrke sykepleiernes kliniske vurderingsevne, og at verktøyet dannet grunnlag for å vurdere hvilke pasienter som hadde behov for høyere grad av overvåkning, og hvilke tiltak som ble iverksatt $(11,12,16,17)$. NEWS-skåren ble også ulikt vurdert på medisinsk og kirurgisk avdeling (17), og noen sykepleiere hadde erfaringer med å ta flere målinger enn dem som inngikk i NEWSprotokollen, for å danne et helhetlig bilde av pasienten (13, 15-17).

Sykepleiere opplevde også at NEWS ble brukt til å bekrefte egen intuisjon eller «magefølelse» $(10,12,15,17,19)$. I noen studier mente sykepleierne at en kombinasjon av objektive målinger, observasjoner og individuell kompetanse ble brukt for å vurdere den enkelte pasientens tilstand, noe som kunne føre til at sykepleiernes egen intuisjon ikke stemte overens med NEWS-målingene, og at det dermed opplevdes som vanskelig å gjøre vurderinger av pasienten (12, 14, 15, 19).

\section{$\equiv$ «Noen sykepleiere mente at NEWS burde tilpasses den enkelte pasienten.»}


Andre studier viste at noen sykepleiere kun brukte egen kompetanse og vurdering fordi de opplevde det som vanskelig å «stole på et tall» (10, 16, 17, 19). En sykepleier sa: «Jeg ser ingen fordel med [NEWS]; tross alt har erfarne sykepleiere dette 'i ryggraden', og det er grunnleggende sykepleiekunnskap» (16).

I flere studier opplevde sykepleiere at NEWS-protokollen ikke tok hensyn til underliggende sykdom (det vil si kronisk sykdom som kan påvirke NEWS-skåren), noe som kan føre til at en forhøyet skår kan være «normal» $(13,19)$. Noen sykepleiere mente derfor at NEWS burde tilpasses den enkelte pasienten $(13,19)$.

Sykepleiere hadde ulike erfaringer med å justere referanseverdier til de vitale parametrene som ble målt i NEWS-protokollen, og med hvem som skulle justere referanseverdiene til pasienter med underliggende sykdom $(10,13-15,19)$. Noen sykepleiere mente at de kunne gjøre dette selv, mens andre hadde erfaring med å henvende seg til lege og mente at dette var en legeoppgave $(14,15,19)$. Enkelte opplevde at leger sjelden gjorde endringer i referanseverdiene ved underliggende sykdom $(14,15)$.

\section{Sykepleiere følte seg tryggere når de kunne henvise til en NEWS-skår}

De fleste studiene viste at NEWS styrket samarbeidet og kommunikasjonen mellom sykepleiere og andre yrkesgrupper $(10,11,15,16,18,19)$, selv om flere studier viste til sykepleieres erfaringer med å utsette og kontakte lege ved forhøyet NEWS-skåre $(14-17,19)$.

I en studie oppga en sykepleier aldri å ha tilkalt en lege for en EWS på 3 fordi svaret fra legen var forventet å være å «ta en ny EWS og ring meg igjen hvis det blir verre» (17). Sykepleierne iverksatte heller tiltak selv, som for eksempel å administrere medisin og væske rekvirert på kurve og starte oksygenbehandling (14-16).

Flere studier viste at når sykepleiere stolte på egen kunnskap og følte seg komfortable med å håndtere pasientene selv, kunne dette få betydning for når de kontaktet lege $(14,15,17$, 19). 
To studier viste også at legen ikke alltid tok ansvar når sykepleieren tok kontakt ved forhøyet NEWS-skåre $(12,15)$, og sykepleiere opplevde at de måtte henvise til flere vitale parametre, fordi leger ofte krevde mer informasjon enn bare NEWS-målingene $(9,14,15)$. Samtidig følte sykepleiere seg tryggere når de arbeidet tverrprofesjonelt og $\mathrm{i}$ kommunikasjon med lege, når de kunne henvise til en NEWSskåre $(14,15,18,19)$.

Figur 1. Sykepleieres erfaringer med skåringsverktøyet NEWS

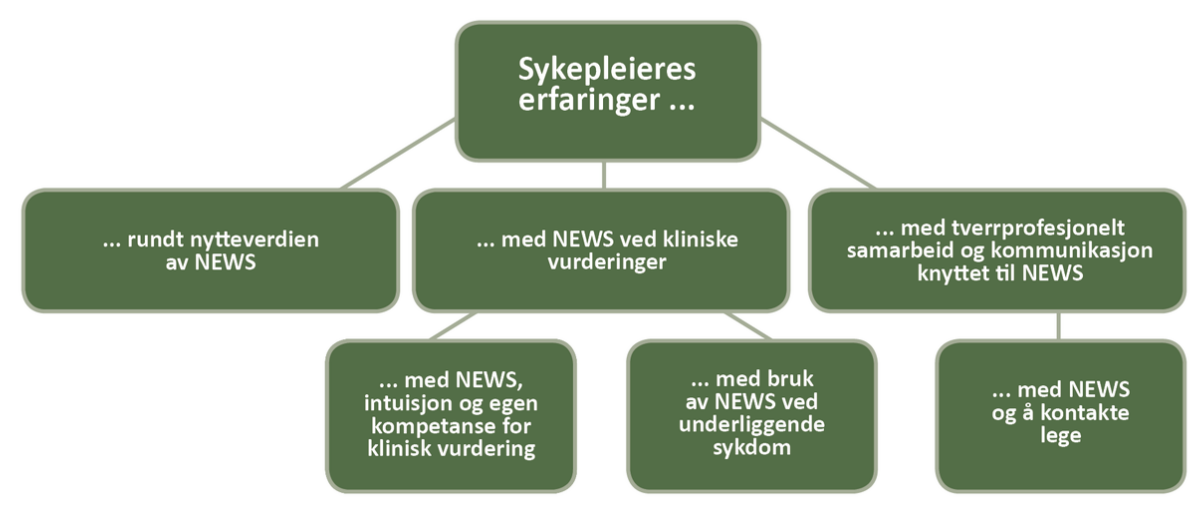

\section{Diskusjon}

Skåringsverktøyet NEWS brukes i flere områder i helsetjenesten, og litteraturstudien belyser viktige tema som kan være av betydning både for utdanningen av sykepleiere og for hvordan NEWS brukes av erfarne og mindre erfarne sykepleiere.

\section{NEWS er viktig for raskt å oppdage forverring}

En norsk studie viser at skåringsverktøyet bidrar til en $\varnothing \mathrm{kning}$ i målinger av vitale parametre hos pasienter innlagt på sykehus, noe som fører til at sykepleiere tidligere oppdager en forverring i pasientens kliniske tilstand (20). Dette samsvarer med våre funn. Vår studie viser at sykepleiere mener at både objektive målinger og observasjoner, samt sykepleieres personlige kompetanse og erfaring, må brukes for å vurdere den enkelte pasientens tilstand.

Kunnskap og kompetanse kan hjelpe sykepleiere med å vurdere og forstå sammenhengen i observasjoner på en god måte (21). Observasjoner handler om å se helhetlig på pasientens tilstand og ikke kun registrere tegn eller symptomer (22). 
Dette er i tråd med Helsedirektoratets anbefaling om at sykepleiere skal bruke skåringsverktøyet sammen med egen kompetanse og kliniske skjønn, og ikke alene, for å utføre helhetlige kliniske vurderinger (1). Dette samsvarer også med hva vi erfarte i praksisstudiene, der NEWS ofte ble brukt sammen med andre observasjoner for å kunne danne et helhetlig bilde av pasientens tilstand.

I forbindelse med covid-19-utbruddet våren 2020 viste en norsk studie at NEWS2-målinger ved innkomst kunne være nyttig for å identifisere pasienter i risikogruppen for svært alvorlige sykdomsforløp (6). Vi mener at selv om NEWS ikke gir et fullstendig og helhetlig bilde av pasientens tilstand, har verktøyet en viktig plass som en del av sykepleierens observasjoner for raskt å oppdage forverring av tilstanden.

\section{Intuisjon og NEWS er et godt grunnlag for klinisk vurdering}

Flere studier viste at noen sykepleiere brukte NEWS til å bekrefte sin kliniske intuisjon, mens andre fikk problemer med å forsvare sin vurdering av pasienten og å formidle denne videre uten egen intuisjon og kompetanse (10, 12, 15, $17,19)$.

Sykepleiere utvikler intuisjon gjennom sykepleierstudiet og læringsprosesser over tid, og intuisjon kan bidra til at sykepleiere gjenkjenner tidlige tegn på endring i pasientens tilstand (3).

\section{$\equiv$ «Intuisjon har en plass i sykepleieres vurdering av en pasients tilstand.»}

Sykepleieteoretikeren Patricia Benner (23) hevdet at sykepleieres kliniske kompetanse utvikles fra å arbeide etter prinsipper og regler, til etter hvert å bruke egen intuisjon: Mens nybegynnere følger reglene uten å ha erfaring, bruker eksperten regler sammen med erfart kompetanse. Ifølge Nortvedt og Grønseth (3) handler intuisjon om å knytte en og en enkeltobservasjon sammen til en helhetlig vurdering.

Gjennom sykepleierstudiet har vi opplevd at erfarne sykepleiere oppdaget tegn på forverring hos pasienten tidligere enn uerfarne, men vi har også opplevd at noen sykepleiere er negativt innstilt til bruken av NEWS fordi de mente at egen intuisjon og kompetanse ble tilsidesatt. 
Intuisjon er en del av læringen som det tar tid å utvikle, og vi ser at intuisjon har en plass i sykepleieres vurdering av en pasients tilstand. Også forskningen viser at intuisjon er legitimt å bruke som en del av sykepleierens vurdering av pasienter, og fremfor alt i kompliserte og komplekse situasjoner (24).

\section{Sykepleiere og leger har ulik forståelse}

I vår studie fant vi at sykepleiere i noen tilfeller utsatte å kontakte lege selv om NEWS-retningslinjene sier noe annet, og iverksatte tiltak selv (14-16).

Vi har selv opplevd at sykepleiere gjør selvstendige vurderinger av pasientens NEWS-skår fremfor å kontakte lege umiddelbart når stabile septiske pasienter har forhøyet NEWS-skår over tid, fordi de i enkelte tilfeller mente at pasienten har en underliggende sykdom som forklarer skåren. Sykepleier har derimot kontaktet lege når skåren ble ytterligere forhøyet.

Sykepleiere har varierte erfaringer med bruk av NEWS i praksis og følger ikke alltid skåringsverktøyets protokoll, noe som kan ha sammenheng med for eksempel mangelfull opplæring. Vi mener at dette kan ha konsekvenser for praksis og kan gå ut over pasientsikkerheten i helsevesenet.

\section{$\equiv$ «Noen sykepleiere fryktet at kommunikasjonen ble begrenset til en skår.»}

I tillegg til at skåringskjemaene inneholder observasjoner og vurderinger av vitale parametre, sier skåren også noe om når pasienten trenger tilsyn fra lege (3). Sykepleierne henviser oftere til vitale parametre enn til NEWS-skåren, fordi legen ofte krever mer informasjon om pasienten.

Selv om NEWS bidrar til å styrke kommunikasjonen mellom sykepleiere og andre yrkesgrupper, fant vi også at noen sykepleiere fryktet at kommunikasjonen ble begrenset til en skår, og at andre observasjoner ikke ble inkludert i samme grad som før. 
NEWS tar ikke hensyn til underliggende sykdommer hos pasienter, og inkluderer heller ikke alle kliniske målinger som en sykepleier bør ta av en pasient, noe som kan føre til unødvendige og hyppige målinger. Noen sykepleiere supplerer med flere observasjoner og målinger, mens andre er bekymret for at andre målinger og observasjoner blir glemt.

Vår erfaring etter denne studien er at sykepleiere og leger har ulik forståelse av bruken av NEWS og hvordan de kan samarbeide ved bruken av verkt øyet. Et tema for videre fagutvikling kan være å unders $\varnothing$ ke om bruken av NEWS kan styrkes på tvers av profesjonene.

\section{Konklusjon}

Studien belyser sykepleieres erfaringer med bruken av NEWS i praksis. Funnene viser at NEWS hjalp sykepleiere med å oppdage endringer $i$ vitale parametre og forverring $i$ pasientens tilstand, men at NEWS alene ikke nødvendigvis bidro til å oppdage endring og forverring. Intuisjon og klinisk kompetanse var viktig å bruke sammen med NEWS.

Det kom også frem at sykepleiere ikke alltid forholdt seg til NEWS-protokollen når det gjaldt å kontakte lege, og at legen sjelden justerte parametre hos pasienter med underliggende sykdommer og avvik i normalverdier.

Selv om NEWS ikke alltid ble brukt etter retningslinjene, erfarte sykepleiere at verktøyet styrket den tverrprofesjonelle kommunikasjonen. Mens nyutdannede sykepleiere har lært å bruke NEWS, mangler kanskje erfarne sykepleiere slik opplæring.

Sykepleieres erfaringer med bruk av NEWS i praksis kan tyde på at kunnskapen om og opplæringen i skåringsverktøyet er begrenset, noe som igjen kan ha konsekvenser for videre praksis. Vi tror at tidlig innføring og tverrprofesjonell trening kan styrke bruken av NEWS og dermed pasientsikkerheten i helsevesenet.

\section{Referanser}

1. Helsedirektoratet. Tidlig oppdagelse og rask respons ved forverret somatisk tilstand. Helsedirektoratet; 2020. Tilgjengelig fra: https://www.helsedirektoratet.no/faglige$\mathrm{rad} /$ tidlig-oppdagelse-og-rask-respons-ved-forverretsomatisk-tilstand (nedlastet 17.12.2020). 
2. Jensen JK, Skår R, Tveit B. The impact of Early Warning Score and Rapid Response Systems on nurses' competence: an integrative literature review and synthesis. $\mathrm{J}$ Clin Nurs. 2018;27(7-8):e1256-e74.

3. Nortvedt P, Grønseth R. Klinisk sykepleie - funksjon, ansvar og kompetanse. I: Stubberud DG, Grønseth R, Almås H, red. Klinisk sykepleie 1. Oslo: Gyldendal Akademisk; 2016. s. $18-37$.

4. Kramer AA, Sebat F, Lissauer M. A review of early warning systems for prompt detection of patients at risk for clinical decline. J Trauma Acute Care Surg. 2019;87(1S Suppl 1):S67-S73.

5. Royal College of Physicians. National Early Warning Score (NEWS) 2. 2017 Guidelines. Tilgjengelig fra:

https://www.rcplondon.ac.uk/projects/outputs/national-earlywarning-score-news-2 (nedlastet 18.12.2O20).

6. Ihle-Hansen H, Berge T, Tveita A, Rønning EJ, Ern $\varnothing$ PE, Andersen EL, et al. COVID-19: symptoms, course of illness and use of clinical scoring systems for the first 42 patients admitted to a Norwegian local hospital. Tidsskr Nor Legeforen. 2020;140(7).

7. Nortvedt M, Jamtvedt G, Graverholt B, Nordheim LV, Reinar LM. Jobb kunnskapsbasert: en arbeidsbok. 2. utg. Oslo: Akribe; 2012.

8. Evans D. Systematic reviews of interpretive research: interpretive data synthesis of processed data. Aust J Adv Nurs. 2002;20(2):22-6.

9. Andrews T, Waterman H. Packaging: a grounded theory of how to report physiological deterioration effectively. J Adv Nurs. 2005;52(5):473-81.

10. Brangan E, Banks J, Brant H, Pullyblank A, Le Roux H, Redwood S. Using the National Early Warning Score (NEWS) outside acute hospital settings: a qualitative study of staff experiences in the West of England. BMJ open.

2018;8(10):eo22528.

11. Burns KA, Reber T, Theodore K, Welch B, Roy D, Siedlecki SL. Enhanced early warning system impact on nursing practice: a phenomenological study. J Adv Nurs. 2018;74(5):1150-6. 
12. Dalton M, Harrison J, Malin A, Leavey C. Factors that influence nurses' assessment of patient acuity and response to acute deterioration. Br J Nurs. 2018;27(4):212-8.

13. Donohue LA, Endacott R. Track, trigger and teamwork: communication of deterioration in acute medical and surgical wards. Intensive Crit Care Nurs. 2010;26(1):10-7.

14. Foley C, Dowling M. How do nurses use the early warning score in their practice? A case study from an acute medical unit. J Clin Nurs. 2019;28(7-8):1183-92.

15. Jensen JK, Skår R, Tveit B. Hospital nurses’ professional accountability while using the National Early Warning Score: a qualitative study with a hermeneutic design. J Clin Nurs. 2019;28(23-24):4389-99.

16. Jensen JK, Skår R, Tveit B. Introducing the National Early Warning Score - a qualitative study of hospital nurses' perceptions and reactions. Nurs Open. 2019;6(3):1067-75.

17. Petersen JA, Rasmussen LS, Rydahl-Hansen S. Barriers and facilitating factors related to use of early warning score among acute care nurses: a qualitative study. BMC Emerg Med. 2017;17(1):36.

18. Stafseth SK, Grønbeck S, Lien T, Randen I, Lerdal A. The experiences of nurses implementing the Modified Early Warning Score and a 24-hour on-call Mobile Intensive Care Nurse: an exploratory study. Intensive Crit Care Nurs. 2016;34:25-33.

19. Stewart J, Carman M, Spegman A, Sabol VK. Evaluation of the effect of the modified early warning system on the nurse-led activation of the rapid response system. $\mathrm{J}$ Nurs Care Qual. 2014;29(3):223-9.

20. Granaas M, Vatn L, Lund SB. Fanger opp forverring tidligere. Sykepleien. 2016. Tilgjengelig fra: https://sykepleien.no/forskning/2016/05/systematiskobservasjon-av-darlige-pasienter (nedlastet 17.12.2020).

21. Skaug E-A. Kliniske vurderingsprosesser og dokumentasjon av sykepleie. I: Kristoffersen NJ, Nortvedt F, Skaug E-A, Grimsbø GH, red. Grunnleggende sykepleie. Bind 1. Oslo: Gyldendal Akademisk; 2017. s. 337-76. 
22. Flovik AM, Normann L, Mølstad K. Sykepleie - et selvstendig og allsidig fag. 2008. Tilgjengelig fra:

https://docplayer.me/8116742-Sykepleie-et-selvstendig-og-

allsidig-fag.html (nedlastet 18.12.2020).

23. Benner P, Tanner C. Clinical judgment: How expert nurses use intuition. Am J Nurs. 1987;87(1):23-34.

24. Rew L, Barrow EM jr. State of the science: intuition in nursing, a generation of studying the phenomenon. Adv Nurs Sci. 2007;30(1):E15-25. 